\title{
Penguatan Peran Ibu dalam Pola Pendampingan Terhadap Anak dan Media Baru
}

\author{
${ }^{1)}$ Nur Amala Saputri, ${ }^{2)}$ Tommy Satriadi Nur Arifin \\ Program Studi Ilmu Komunikasi, Fakultas Ilmu Sosial dan Ilmu Politik \\ Universitas Widya Mataram \\ email: amalasaputri@gmail.com
}

\begin{abstract}
Abstrak
Hadirnya media baru memperlihatkan perubahan besar dalam kehidupan masyarakat. Ibu sebagai pendidik keluarga harus mempunyai pengetahuan dan pemahaman mengenai media baru. Agar dapat mendidik anak-anak dan keluarga dalam menggunakan media baru secara baik. Kegiatan pengabdian ini bertujuan untuk memberikan pengetahuan mengenai media baru, khususnya dalam pola pendampingan ibu terhadap anak dan media. Metode yang digunakan adalah refleksi, ceramah, simulasi, dan diskusi perihal media baru. Peserta yang mengikuti kegiatan ini adalah ibu-ibu PKK Dusun Demen usia 25-60 tahun. Hasil dari kegiatan ini adalah terdapat 6 pola yang digunakan oleh ibu-ibu dalam mendampingi anak dan media. Pola tersebut adalah (1) Para ibu harus bisa memahami dan mengidentifikasi informasi atau konten yang dapat dikonsumsi oleh anak. (2) Mengatur waktu anak dalam menggunakan media baru. (3) Menggunakan mode safe (aman) saat anak sedang mengoperasikan smartphone, khususnya bagi anak usia Sekolah Dasar ke bawah. (4) Melakukan pengawasan dan pengecekkan smartphone yang digunakan oleh si anak. (5) Mengajak anak untuk mengobrol dan berdiskusi mengenai kegiatan mereka sehari-hari setelah anak beristirahat, di samping itu juga membuat grup keluarga di Whatsapp sebagai ruang keluarga untuk mengobrol secara online. (6) Mengadukan atau melaporkan konten hoax dan konten-konten yang mengandung isu SARA negatif. Ibu-ibu PKK yang mengikuti kegiatan ini banyak memberikan respon positif dan menjadi lebih paham dalam menggunakan media baru khususnya saat mendampingi si anak saat mengoperasikan media baru.
\end{abstract}

Kata Kunci: Literasi Media Baru, Ibu, Pendampingan, Anak

\begin{abstract}
The presence of new media changes major changes in people's lives. Mothers as family educators must have the knowledge and understanding of new media. In order to educate children and families in using new media well. This service activity is intended to provide knowledge about new media, specifically in the pattern of mother to child assistance and the media. The methods used are reflection, lectures, simulations, and discussions about new media. Participants who took part in this activity were PKK Mothers of Demen village aged 25-60 years. The results of this activity include 6 patterns used by mothers in assisting children and the media. The pattern is (1) Mothers must be able to argue and ask for information or content that can be paid by the child. (2) Set the time for children to use new media. (3) Using safe mode when the child is operating a smartphone, specifically for elementary school age children down. (4) Supervise and check the smartphone used by the child. (5) Inviting children to chat and discuss their daily activities after children, while also making family groups on Whatsapp as a family room to chat online. (6) Combine or report deceptive content and content that contains negative SARA issues. PKK Mothers who participated in this activity gave many positive responses and became more understanding in using new media when accompanying the child when using new media.
\end{abstract}

Keywords: New Media Literacy, Mother, Mentoring, Children

\section{Pendahuluan}

Kebutuhan akan pemahaman bermedia dalam khalayak sangatlah penting. Hampir dalam setiap aktivitas manusia sehari-hari selalu menggunakan media baru. Kecanggihan media pun semakin lengkap dengan adanya fitur-fitur beragam yang membuatnya menjadi alat multifungsi. Seperti halnya dengan aplikasi jejaring sosial yang menyediakan ruang untuk melakukan interaksi sosial secara virtual. Lalu aplikasi game yang berfungsi untuk menghibur. Adapula aplikasi youtube yang fungsinya menyajikan konten audiovisual yang sangat bervariatif, dan fitur-fitur lainnya. Dengan kelebihannya yang luar biasa ini, sering kali kita terbuai dengan keindahan 
fitur-fitur media digital, tanpa memahami fungsinya secara mendasar. Sehingga media digital sering disalahgunakan, bahkan dapat memberikan dampak buruk bagi masyarakat.

$\begin{array}{llr}\text { Pada tahun } 1994 & \text { Marshall } \\ \text { McLuhan menyebut "Kita yang }\end{array}$ membentuk alat-alat dan setelah itu alatalat yang membentuk kita" (McLuhan, 1994:20). Sesungguhnya teknologi media baru diciptakan demi mempermudah manusia dalam berkomunikasi dan berinteraksi sosial. Bahkan dia hadir sebagai bentuk solusi permasalahan keterbatasan komunikasi dalam jarak, ruang, dan waktu. Dalam media baru, manusia berperan sebagai pengguna media, yakni sebagai agen aktif yang memproduksi pesan. Memang terdapat perubahan yang signifikan dalam penggunaan media baru, tak seperti media konvensional yang sifat audiensnya masih cenderung pasif. Menjadi agen atas ruang media digital tentu saja membicarakan aksesbilitas terhadap ruang produksi pesan. Disinilah pemasalahan komunikasi timbul, contohnya seperti penyebaran konten hoax, cyberbullying, cyberseks, penyebaran konten kebencian dan lainlain.

Dalam tatanan kelompok sosial di masyarakat, "keluarga merupakan kelompok terkecil yang terdiri dari ayah, ibu, dan anak" (Goode, 2004:67). Posisi ibu mempunyai peranan penting dalam keluarga, yakni sebagai pendidik keluarga. Ajaran Jawa mengajarkan mengenai keluarga inti konjugal yang disebut Engles sebagai keluarga borguise yang mencerminkan relasi head complement yang bertumpu pada karir dan penghasilan utama suami dan peran domestik istri sebagai ibu rumah tangga (Rosalind, 1987:133). Peran domestik yang dimaksud adalah menekankan pada tanggung jawab ibu pada urusan privat keluarga yang didalamnya menyangkut pengaturan ekonomi keluarga, ketersediaan sandang dan pangan bagi keluarga, termasuk pendidikan pada anak. Atas dasar pemikiran tersebut, kegiatan pengabdian ini mengarah pada sosok ibu rumah tangga yang diharapkan tidak hanya memiliki kemampuan analisis terhadap media tetapi juga dapat menjadi agen perubahan pada keluarganya.

Kegiatan Pengabdian Masyarakat ini dilaksanakan di Dusun Demen, Pakembinangun, Pakem, Sleman, Yogyakarta. Dusun Demen sendiri terbilang desa penggiran yang tengah mengalami perubahan modern semenjak munculnya media baru. Masyarakatnya mulai memanfaatkan media jejaring sosial sebagai alat komunikasi untuk menyebarkan informasi seputar Dusun Demen, khususnya bagi kelompok ibu-ibu Demen. Ibu Rumah Tangga di Dusun Demen memiliki agenda rutin mingguan dan bulanan, yakni kelompok yasinan, kelompok koperasi, kelompok arisan RT, dan kelompok PKK. Kegiatan ini diikuti seluruh ibu rumah tangga, yang beranggotakan kurang lebih 60 orang. Pengabdian ini bermaksud untuk memberikan pemahaman media baru bagi ibu-ibu, khususnya dalam pola pendampingan ibu terhadap anak dan media.

\section{Metode}

Kegiatan penguatan peran ibu dalam pola pendampingan terhadap anak dan media baru menggunakan metode refleksi, ceramah, simulasi, dan diskusi perihal media baru. Peserta yang mengikuti kegiatan ini adalah ibu-ibu usia 25-60 tahun sebanyak 40 peserta dipilih dengan cara meminta pertimbangan dari para pemangku wilayah dengan berdasar pula dari analisis kondisi-kondisi keluarga yang ada. Selanjutnya, kegiatan ini dipandu oleh 4 orang fasilitator yang berkompetensi dalam bidang media baru yang bergelar magister, yakni tim Dosen Ilmu Komunikasi Universitas Widya Mataram (salah satunya adalah penulis). Fasilitator di sini berperan memfasilitasi peserta untuk menemukan cara pendampingan anak dalam dalam bermedia digital dan menemukan media alternatif yang dapat dijadikan referensi bermedia untuk anak.

Teknik pelaksanaanya adalah dengan membentuk kelompok-kelompok kecil. Setiap fasilitor memimpin kelompok 
kecil tadi untuk berdiskusi mengenai "cara pendampingan anak dalam bermedia oleh keluarga". Sebagai awalan, fasilitasor memberikan penjelasan singkat mengenai definisi dan bentukbentuk media baru. Kemudian, dilakukan proses tanya-jawab antara fasilitator dengan ibu-ibu dalam rangka untuk membangun diskusi mengenai media baru ini. Capaian kegiatan diskusi ini diharapkan; peserta dapat menemukan pola pendampingan ideal untuk anak dalam keluarga dan menemukan mediamedia alternatif untuk anaknya.

\section{Hasil dan Pembahasan}

Pada pelakasaan kegiatan pengabdian tanggal 1 Desember 2018 di Dusun Demen, ibu-ibu PKK sangat terlihat antusias dalam mengikuti kegiatan ini. Acara ini juga dihadiri oleh bapak Mujono selaku Dukuh Dusun Demen. Proses kegiatan pengabdian yang berfomat diskusi ini menggunakan dua pokok bahasan, yakni; penggunaan media baru oleh ibu-ibu PKK, dan peran ibu dalam pendampingan terhadap anak dan media baru. Prosesi diskusi dimulai dengan memberikan pengantar mengenai definisi media dan penjelasan singkat mengenai sejarah media massa di Indonesia. Selanjutnya ibu-ibu diberikan tugas untuk menyebutkan bentuk-bentuk dan fungsi media sepengetahuan mereka. Hasilnya, ternyata sebagian besar ibu-ibu sudah mengetahui bentuk-bentuk, dan fungsi media massa konvensional (televisi, radio, koran). Sedangkan pada pemahaman bentuk dan fungsi media baru masih terbilang sedikit.

Proses diskusi dilanjutkan dengan fasilitator menjelaskan mengenai fenomena kehadiran media baru (internet) yang tengah kita alami saat ini. Hampir seluruh ibu-ibu PKK Dusun Demen telah menggunakan smartphone sebagai salah satu bentuk alat komukasi dalam kategori media baru. Lalu fasilator meminta ibu-ibu untuk bercerita mengenai bagaimana mereka menggunakan smartphone setiap harinya. Ada salah satu ibu yang menceritakan bahwa beliau banyak menggunakan aplikasi sosial media seperti Whatsapp, Youtube, Facebook, dan
Instagram. Sedangkan dalam kelompok tersebut rata-rata ibu-ibu lebih banyak menggunakan Whatsapp dan Facebook.

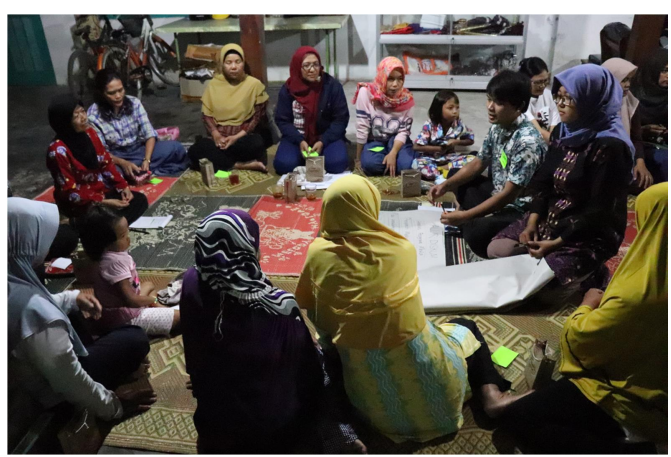

Gambar. 1. Pembukaan proses diskusi oleh fasilitator dengan menjelaskan fenomena media komunikasi dan media baru (sumber: Dokumen penulis, Desember 2018).

Ibu-ibu tersebut mengaku menggunakan media sosial tersebut untuk chating dan mencari informasi. Salah satu bentuk penggunaanya adalah menggunakan aplikasi whatsaap untuk membentuk grup chating ibu-ibu PKK Dusun Demen. Grup whatsaap tersebut digunakan sebagai tempat untuk koordinasi agenda kegiatan ibu-ibu PKK. Di samping itu, ternyata beberapa ibu-ibu PKK menggunakan grup tersebut untuk membagikan informasi mengenai fenomena sosial yang sedang menjadi trending atau populer. Buruknya adalah, sebagian ibu-ibu PKK pengguna media baru tersebut masih seringkali secara langsung larut dalam isu sosial yang menjadi trending tersebut. Mereka belum bertindak untuk mengecek sumber dan kebenaran terkait dengan isu tersebut. Apalagi mengenai isu hoax yang akhirakhir ini sedang menjadi banyak perbincangan dalam media maupun masyarakat.

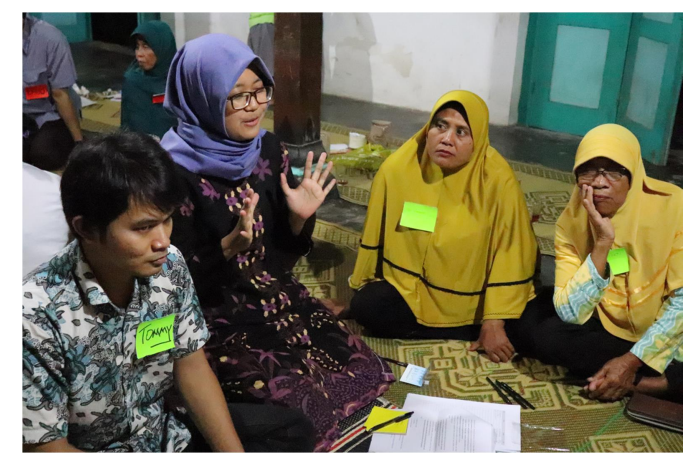


Gambar. 2. Salah satu fasilitator memberikan tips mengenai cara menghadapi hoax. (sumber: Dokumen penulis, Desember 2018).

Pada tahap ini, fasilitator kemudian memberikan penjelasan mengenai hoax dan memberikan tips kepada ibu-ibu dalam menghadapi permasalahan hoax dan penyebaran informasi yang belum jelas tersebut. Pertama, fasilitator memberikan saran untuk para ibu-ibu tersebut selalu mengecek dan menanyakan sumber informasi yang mereka peroleh kepada si penyebar/pengirim informasi. Kedua, bilamana si pengirim informasi tidak mengetahui sumbernya, maka ibu-ibu diharapkan untuk bisa mengecek kredibilitas informasi melalui Google atau situs-situs media yang jelas ataupun resmi.

Diskusi dilanjutkan dengan bahasan kedua mengenai peran ibu dalam pendampingan terhadap anak dan media. Dalam bahasan ini, fasilitator menanyakan mengenai peran ibu dalam keluarga sebagai pendidik anak-anak mereka. Sebagaimana peran ibu dalam mendidik dan mengawasi anak saat menggunkan media baru. Selama proses diskusi, ratarata ibu-ibu sudah mengontrol anak dalam segi waktu pemakaian. Para ibu yang masih memiliki anak usia Sekolah Dasar ke bawah biasanya memperbolehkan si anak meminjam smartphone saat sedang hari libur atau setelah mengerjakan tugas sekolah (PR).

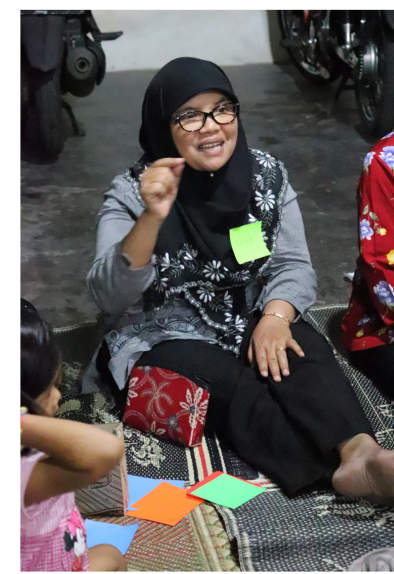

Gambar. 3. Salah satu ibu menjelaskan mengenai penggunaan mode aman (safe mode) pada smartphone saat mendampingi anak. (sumber: Dokumen penulis, Desember 2018).

Di sisi lain, ada salah satu ibu yang sudah memahami untuk menggunakan mode safe (aman) saat anaknya sedang meminjam smartphone. Dengan demikian si ibu dapat memantau anaknya dalam menggunakan smartphone, seperti aplikasi apa saja yang digunakan oleh si anak, dan situs-situs apa saja yang dibuka oleh si anak. Namun sebagian besar anak-anak usia dibawah Sekolah Dasar ternyata membuka situs Youtube dan membuka aplikasi game pada smartphone ibu. Sedangkan bagi ibu-ibu yang memiliki anak usia Sekolah Menengah Pertama (SMP) ke atas, pengawasan lebih dilakukan pada aksi mengecek handphone milik si anak dan membuat grup keluarga dalam Whatsaap. Hal ini dikarenakan, ada beberapa ibu yang menyekolahkan anaknya di sekolah yang mengharuskan anak untuk mempunyai smartphone. Sehingga edukasi dan pengawasan anak lebih mengarah pada upaya untuk sering mengajak anaknya mengobrol dan bercerita mengenai kesehariannya di luar rumah.

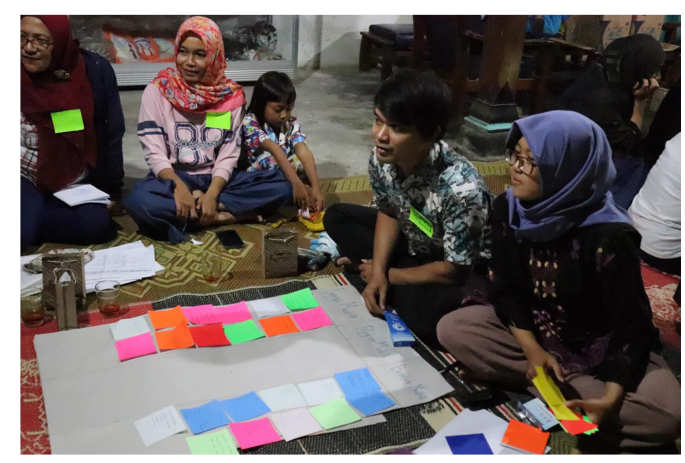

Gambar. 4. Fasilitator memberikan penjelasan mengenai tata cara mengadukan konten negatif dalam media sosial. (sumber: Dokumen penulis, Desember 2018).

Sebagai penutup diskusi, fasilitator mengajak para ibu untuk aktif melakukan pengaduan terhadap kontenkonten hoax maupun isu SARA negatif dengan memberikan pengetahuan mengenai tata cara pengaduan konten di media sosial. Upaya ini dilakukan demi meningkatkan pola ibu dalam pendampingan terhadap anak dan media. 
Berdasarkan hasil diskusi mengenai media baru yang dilakukan oleh fasilitator dan ibu-ibu PKK Dusun Demen, penulis menemukan 6 pola yang digunakan oleh ibu-ibu dalam mendampingi anak dan media, yakni:

1. Para ibu harus bisa memahami dan mengidentifikasi informasi atau konten yang dapat dikonsumsi oleh anak.

2. Mengatur waktu anak dalam menggunakan media baru.

3. Menggunakan mode safe (aman) saat anak sedang mengoperasikan smartphone, khususnya bagi anak usia Sekolah Dasar ke bawah.

4. Melakukan pengawasan dan pengecekkan smartphone yang digunakan oleh si anak.

5. Mengajak anak untuk mengobrol dan berdiskusi mengenai kegiatan mereka sehari-hari setelah anak beristirahat, di samping itu juga membuat grup keluarga di Whatsapp sebagai ruang keluarga untuk mengobrol secara online.

6. Mengadukan atau melaporkan konten hoax dan konten-konten yang mengandung isu SARA negatif.

\section{Kesimpulan}

Kegiatan penguatan peran ibu dalam pola pendampingan terhadap anak dan media baru yang dilakukan bersama ibu-ibu PKK Dusun Demen ini berjalan dengan lancar dan baik. Antusiasme para ibu PKK tersebut sangat tinggi, hal ini dikarenakan selama ini mereka belum pernah mendapatkan literasi media baru. Dengan demikian pengetahuan media baru ibu-ibu PKK Dusun Demen masih terbilang minim sebelum mengikuti kegiatan literasi media baru yang dilakukan oleh tim Dosen Ilmu Komunikasi Universitas Widya Mataram. Ibu-ibu PKK yang mengikuti kegiatan tersebut banyak memberikan respon positif dan mengaku menjadi lebih paham dalam menggunakan media baru khususnya saat mendampingi si anak saat mengoperasikan media baru. Oleh karenanya, literasi media baru sangatlah penting dilakukan demi mewujudkan masyarakat Indonesia yang cerdas bermedia.

\section{Daftar Pustaka}

Goode, William. J. 2004. Bunga Rampai Sosiologi Keluarga. Jakarta: Yayasan Obor Indonesia.

A. Sydie, Rosalind. 1987. Natural Women and Cultured Men: A Feminist Perpective on Sociological Theory. England: Open University Press.

Darmanto, dkk. 2012. Ibu Rumah Tangga Melawan Televisi. Yogyakarta: YayasanTifa.

McLuhan, Marshall. 1994. Understanding Media The Extension of Man. Massachusetts Institute of Technology Pres.

Barker, Chris. 1999. Television, Globalization and Cultural Identities. Buckingham: Open University Press. 